\title{
L'insonnia in una notte d'estate
}

Mi sono messo a giacere sotto le stelle, una di quelle notti che fanno dell'insonnia tetra un religioso piacere. Il mio guanciale è una pietra.

Siede, a due passi, un cane. Siede immobile e guarda sempre un punto, Iontano. Sembra quasi che pensi, che sia degno di un rito, che nel suo corpo passini $i$ silenzi dell'infinito.

Di sotto un cielo così turchino, in una notte così stellata, Giacobbe sognò la scalata d'angeli di tra il cielo e il suo guanciale, ch'era una pietra.

In stelle innumerevoli il fanciullo contava la progenie sua a venire; in quel paese ove fuggiva l'ire de1 più forte Esaù, un impero incrollabile nel fiore della richezza per il figli suoi; e l'incubo del sogno era il Signore che lottava con 1ui. 
Insomnia on a Summer Night

I stretched out

beneath the stars,

one of those

nights which make of dark insomnia

a religious pleasure.

My pillow is a stone.

There sits, two steps away, a dog.

He sits immobile and looks

always at a point, far away.

It seems almost that he is thinking,

that he is worthy of a rite,

that in his body there pass the silences

of the infinite.

Under a sky so deep blue,

on a night as starlit,

Jacob dreamed the climb

of angels between the sky and his pillow,

which was a stone.

In innumerable stars the boy

counted his offspring to come;

in that country where the fury

of the stronger Esau escaped,

an unshakable empire in the bloom

of riches for its sons;

and the nightmare of the dream was the Lord who struggled with him. 